\title{
HOTEL RESORT DANAU LAIT
}

\author{
Arif Affandi', Jawas Dwijo Putro ${ }^{2}$, Emilya Kalsum ${ }^{3}$ \\ ${ }^{1}$ Mahasiswa, Jurusan Arsitektur, Fakultas Teknik, Universitas Tanjungpura. \\ arif.pzm@gmail.com \\ ${ }^{2}$ Jurusan Arsitektur, Fakultas Teknik, Universitas Tanjungpura \\ ${ }^{3}$ Jurusan Arsitektur, Fakultas Teknik, Universitas Tanjungpura
}

Naskah diajukan pada: 24 Juni 2021

Naskah revisi akhir diterima pada: 3 Juli 2021

\begin{abstract}
Abstrak
Danau Lait mulai terkenal setelah viral di media sosial karena keindahan dan keunikan alamnya. Lokasi terletak di Desa Subah, Kabupaten Sanggau yang berada pada Provinsi Kalimantan Barat. Saat ini Danau Lait mulai banyak didatangi masyarakat. Berdasarkan referensi tentang jumlah pengunjung di Danau Lait dalam beberapa bulan terakhir mencapai lebih dari 8000 pengunjung. Lonjakan pengunjung Danau Lait tidak diimbangi dengan adanya akomodasi yang mewadahi kebutuhan pengunjung. Oleh karena itu, diperlukan suatu wadah atau tempat untuk refreshing dan beristirahat yang nyaman bagi pengunjung yaitu berupa hotel Resort. Fungsi dari hotel Resort tidak hanya sebagai sarana menginap, namun juga sarana untuk menikmati wisata alam yang berada di sekitar Danau Lait. Perancangan hotel Resort ini menggunakan konsep pendekatan Neo-vernakular yaitu perpaduan konsep bangunan tradisional dan bangunan modern yang ditekankan pada fasad bangunan. Penggunaan konsep ini juga bertujuan untuk memberikan ciri khas pada bangunan Hotel Resort Danau Lait. Berdasarkan permasalahan yang ada, dimungkinkan untuk terciptanya suatu penginapan dengan pendekatan Neo-vernakular yang bisa dinikmati oleh orang banyak. Pembangunan hotel Resort ini diharapkan dapat mengakomodir kebutuhan wisatawan yang berkunjung ke Danau Lait.
\end{abstract}

Kata-kata Kunci: Hotel Resort, Danau Lait, Neo-vernakular

\begin{abstract}
Danau Lait became famous after going viral on social media because of its natural beauty and uniqueness. Located in Subah Village, Sanggau Regency in West Kalimantan Province. Currently, Danau Lait is starting to be visited by many people. Based on references to the number of visitors to Lake Lait in recent months, it has reached more than 8000 visitors. The surge in visitors to Lake Lait is not matched by the accommodation that accommodates the needs of visitors. Therefore, we need a place or place for refreshing and comfortable rest for visitors, namely in the form of a Resort hotel. The function of a Resort hotel is not only to stay but also to enjoy the natural attractions of Danau Lait. The design of this Resort hotel uses the concept of a Neo-vernacular approach, which is a combination of the concept of traditional buildings and modern buildings which are emphasized on the building's facade. The use of this concept also aims to give an identity to the Hotel Resort Danau Lait building. Based on the existing problems, it is possible to create a Resort hotel with a Neo-vernacular approach that can accommodate the needs of tourists visiting Danau Lait.
\end{abstract}

Keywords: Resort Hotel, Danau Lait, Neo-vernacular

\section{Pendahuluan}

Danau Lait mulai terkenal setelah viral di media sosial karena keindahan dan keunikan alamnya. Lokasinya terletak di Desa Subah, Kecamatan Tayan Hilir, Kabupaten Sanggau Kalimantan Barat. Jarak dari Kota Pontianak menuju Danau Lait ini berjarak sekitar $80 \mathrm{~km}$ atau sekitar 1,5 jam perjalanan darat dari arah kota Pontianak menuju ke Tayan. Akses jalan menuju Danau Lait berupa jalan beton dan tanah. Rute perjalanan tidak terlalu jauh sekitar $5 \mathrm{~km}$ dari Jalan Trans Kalimantan. Danau ini mempunyai luas yang lebar sekitar \pm 800 hektar. Hamparan air danau yang luas dikelilingi hutan tropis serta beberapa perbukitan yang menambah kesan keindahan pada 
objek wisata ini dan kaya akan satwa yang hidup di dalamnya. Danau Lait memiliki kenunikan tersendiri yang membedakan dengan danau-danau yang lain yang ada di Kalimantan Barat. Yaitu danau ini dikelilingi oleh 12 bukit kecil yang tersebar di segala penjuru danau. Air yang cukup jernih membuat berbagai spesies ikan dapat dilihat dengan jelas. Selain itu danau ini memiliki pulau di tengahnya yang menambah kesan terhadap danau ini. Hal ini merupakan potensi besar yang dimiliki wisata Danau Lait. Selain itu, air pada Danau Lait akan surut pada musim kemarau. Kondisi air danau yang surut menyebabkan orang-orang dapat berjalan di atasnya.

Saat ini Danau Lait mulai banyak didatangi masyarakat. Berdasarkan referensi tentang jumlah pengunjung di Danau Lait dalam beberapa bulan terakhir mencapai lebih dari 8000 pengunjung. Hitungan riilnya bisa jadi melebihi dari jumlah tersebut. Hal ini dikarenakan banyaknya wisatawan tidak hanya dari masyarakat Sanggau saja namun juga banyak dari luar daerah. Mengingat Kabupaten Sanggau juga sebagai border area. Ini bisa menjadi potensi yang akan mendatangkan wisatawan crossborder seperti dari negara tetangga Malaysia dan Brunei. Pengunjung Danau Lait juha berasal dari berbagai macam kalangan dan sering dijadikan sebagai tempat pertemuan bagi berbagai macam komunitas. Oleh karena itu, Danau Lait menjadi pilihan destinasi wisata saat liburan oleh banyak orang.

Lonjakan pengunjung Danau Lait tidak diimbangi dengan adanya akomodasi yang mewadahi kebutuhan pengunjung. oleh karena itu, diperlukan suatu wadah atau tempat untuk refreshing dan beristirahat yang nyaman bagi pengunjung yaitu berupa hotel resort. Menurut Marlina (2008), tujuan pembangunan hotel resort adalah sebagai fasilitas akomodasi dari suatu aktivitas wisata. Ada pula menurut Kurniasih (2006), faktor-faktor adanya suatu hotel resort yaitu berkurang waktu beristirahat, kebutuhan akan rekreasi, keinginan menikmati potensi alam, dan memulihkan kesehatan fisik dan mental. Berdasarkan faktor-faktor yang telah dipaparkan dapat memperkuat alasan dibangunnya hotel resort di Danau Lait.

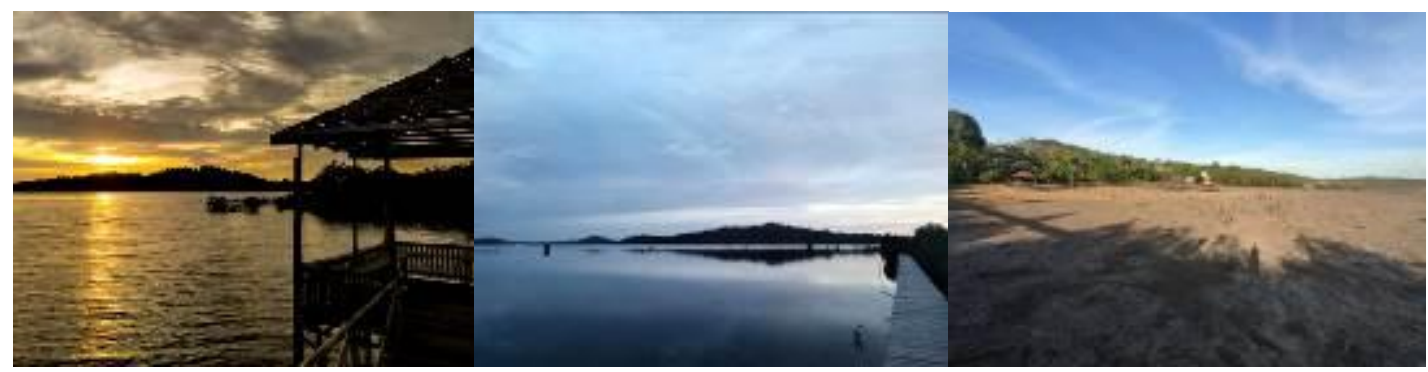

Gambar 1. Danau Lait

Sumber: Dokumentasi Penulis, 2020

\section{Kajian Pustaka}

Hotel resort adalah suatu perubahan tempat tinggal untuk sementara bagi seseorang di luar tempat tinggalnya dengan tujuan antara lain untuk mendapatkan kesegaran jiwa dan raga serta hasrat ingin mengetahui sesuatu. Dapat juga dikaitkan dengan kegiatan olahraga, kesehatan, konvensi, keagamaan, serta keperluan usaha lainnya (Dirjen Pariwisata, 1988).

Menurut John (1987), Hotel resort adalah tempat peristirahatan di musim panas, di tepi pantai atau di pegunungan yang banyak dikunjungi. Pendapat lain dikemukakan oleh (Pendit, 1999), Hotel Resort merupakan sebuah tempat menginap dimana mempunyai fasilitas khusus untuk kegiatan bersantai dan berolahraga seperti tenis, golf, tracking, dan jogging, bagian concierge berpengalaman dan mengetahui betul lingkungan resort, bila ada tamu yang mau hitchhiking berkeliling sambil menikmati keindahan alam sekitar resort ini. Sebuah hotel resort sebaiknya mempunyai lahan yang ada kaitannya dengan objek wisata, oleh sebab itu sebuah hotel resort berada pada perbukitan, lembah, pulung kecil dan juga pinggiran pantai. 
Menurut Kurniasih (2006), faktor-faktor adanya suatu hotel resort yaitu berkurangnya waktu untuk beristirahat, kebutuhan manusia akan rekreasi, keinginan menikmati potensi alam, dan kesehatan. Dapat disimpulkan bahwa dibangunya Hotel Resort di Danau Lait ini dikarenakan oleh faktor kebutuhan manusia akan rekreasi dan keinginan untuk menikmati potensi alam Danau Lait. Adapun karakteristik dari hotel resort yang bisa dibedakan berdasarkan jenis hotel lainnya menurut Kurniasih (2009), yakni berdasarkan lokasi, fasilitas, sasaran pasar, dan atmosfer arsitektur. Oleh karena itu, karakteristik hotel resort jika ditinjau dari lokasi yakni yang berada di Danau Lait berada di dekat objek wisata alam, memiliki fasilitas penunjang baik indoor gym maupun outdoor (berenang, naik perahu, memancing, dan jogging), objek sasarannya ialah tamu atau wisatawan yang ingin berlibur dan rekreasi, serta memiliki arsitektur yang unik sehingga akan memberikan pengalaman tersendiri bagi tamu.

Pada perancangan suatu hotel resort, seorang arsitek harus memahami dan mengetahui terlebih dahulu prinsip-prinsip yang akan digunakan untuk perancangannya. Menurut Kurniasih (2006), menyatakan bahwa penekanan perencanaan hotel resort dengan tujuan pleasure dan rekreasi adalah adanya kesatuan antara bangunan dengan lingkungan sekitarnya, sehingga dapat diciptakan harmonisasi yang selaras. Selain itu, hotel resort juga perlu dilengkapi beberapa fasilitas penunjang seperti sarana rekreasi pantai untuk menarik perhatian wisatawan.

\section{Metode}

Metode perancangan merupakan persyaratan desain dan spesifikasi desain yang akan membahas mengenai data yang dibutuhkan. Data yang terkumpul kemudian dianalisis untuk menarik kesimpulan dan batasan yang jelas mengenai perencanaan dan desain Hotel Resort Danau Lait. Fokus pada masalah makro atau umum ke masalah mikro atau lebih rinci. Menggunakan metode dari R. Whitaker untuk membuat kerangka konseptual arsitektur. Menurut Snyder \& Catanese (1989), tahapan-tahapan yang dilalui yaitu tahap pengenalan, tahap definisi, tahap persiapan, tahap analisis tahap sintesis, tahap evaluasi, dan terakhir tahap re-evaluasi.

\section{Hasil dan Pembahasan}

Landasan konseptual mencakup analisis konsep untuk memperoleh konsep perencanaan dan perancangan Hotel Resort Danau Lait. Proses awal analisis adalah identifikasi permasalahan untuk menemukan solusi perancangan. Perancangan ini menggunakan analisis fungsi, analisis internal, analisis eksternal, analisis bentuk, analisis struktur, analisis utilitas dan analisis fisika bangunan.

\section{Analisis Fungsi}

Analisis fungsi terdiri dari analisis fungsi hotel resort dan analisis klasifikasi hotel resort yang mengacu pada tinjauan teoritik mengenai aktivitas dan kegiatan hotel resort. Pada perancangan Hotel Resort Danau Lait fungsi dibagi menjadi tiga yaitu fungsi primer, sekunder, tersier, dan servis. Fungsi primer pada Hotel Resort Danau Lait yakni sebagai hunian atau tempat beristirahat bagi wisatawan yang berkunjung ke Danau Lait. Fungsi sekunder pada perancangan ini yaitu sebagai tempat rekreasi menikmati keindahan pemandangan alam Danau Lait. Maka dari itu, perlu fasilitas yang menunjang kegiatan tersebut seperti penyewaan perahu, memancing, dan berenang serta fasilitas olahraga dan kebugaran. Fungsi servis bertujuan untuk perawatan, mengatur dan mengontrol serta kegiatan servis pada bangunan agar sistem yang ada pada bangunan berjalan dengan semestinya.

\section{Analisis Internal}

Analisis internal dimaksudkan untuk memperoleh aspek penyusun ruang internal. Pada analisis internal, faktor-faktor yang mempengaruhi berdasarkan dari analisis fungsi perancangan, pelaku dan kegiatan. Kegiatan dari pelaku menghasilkan kebutuhan ruang. Ruang-ruang yang berasal dari 
analisis kegiatan pelaku nantinya akan diolah dan dianalisis dalam persyaratan, besaran, dan hubungan ruang. Analisis pelaku pada perancangan Hotel Resort Danau Lait dibagi berdasarkan rentang waktu pada aktivitas hotel resort. Ada dua jenis pelaku pada hotel resort yaitu pengunjung dan pengelola. Pelaku jenis pengunjung dibagi lagi menjadi pengunjung umum dan tamu hotel yang diperoleh berdasarkan kegiatan menginap atau tidaknya pengunjung.

Pada analisis kegiatan dan kebutuhan ruang diperoleh dari klasifikasi fungsi. Kemudian, dianalisis lebih lanjut berdasarkan jenis fungsi dan jenis aktivitas. Setelah itu, perilaku pelaku kegiatan dianalisis dan dipisahkan menurut sifat ruang yang nantinya akan diperoleh kebutuhan ruang. Kemudian akan dianalisis hubungan antar ruang dimaksudkan untuk menampilkan kedekatan hubungan ruang-ruang yang ada dan juga hubungan antara satu bangunan dengan bangunan lainnya. Pada hubungan ruang diklasifikasikan menjadi lima, yakni dekat terhubung langsung, dekat hubungan tak langsung, jauh tidak berhubungan, dekat namun tidak berhubungan, dan tidak berhubungan.

Pada analisis persyaratan ruang yakni membahas tentang standar dari kenyamanan ruang. Kenyamanan ruang yang dimaksud adalah pencahayaan, termal, dan akustik bangunan. Standar yang digunakan dalam menentukan kenyamanan ruang berdasarkan standar dari (Neufert, 2002).

Analisis pada besaran ruang yakni analisis terhadap kapasitas atau daya tampung ruang, besaran dimensi perabot dan pengguna yang menggunakan ruang. Standar penentuan dimensi diperoleh melalui referensi dari buku. Buku yang digunakan sebagai refresi penentuan besaran ruang yaitu Data Arsitek Jilid 1 (Neufert, 1996), 2 (Neufert, 2002), dan 3 (Neufert, 2002) kemudian ada beberapa ruang yang ditentukan berdasarkan asumsi penulis. Setelah dilakukan analisis terhadap besaran ruang diperoleh besaran total ruang yang diperlukan sebesar $8.740 \mathrm{~m}^{2}$ kemudian dikalikan dengan ruang untuk sirkulasi sebesar 30\% dari total ruang maka didapatkan total luar dari keseluruhan ruang sebesar $11.362 \mathrm{~m}^{2}$. Sisa lahan akan digunakan sebagai ruang terbuka hijau dan area rekreasi alam. Berikut adalah tabel dari perhitungan besaran ruang yang telah di dapat.
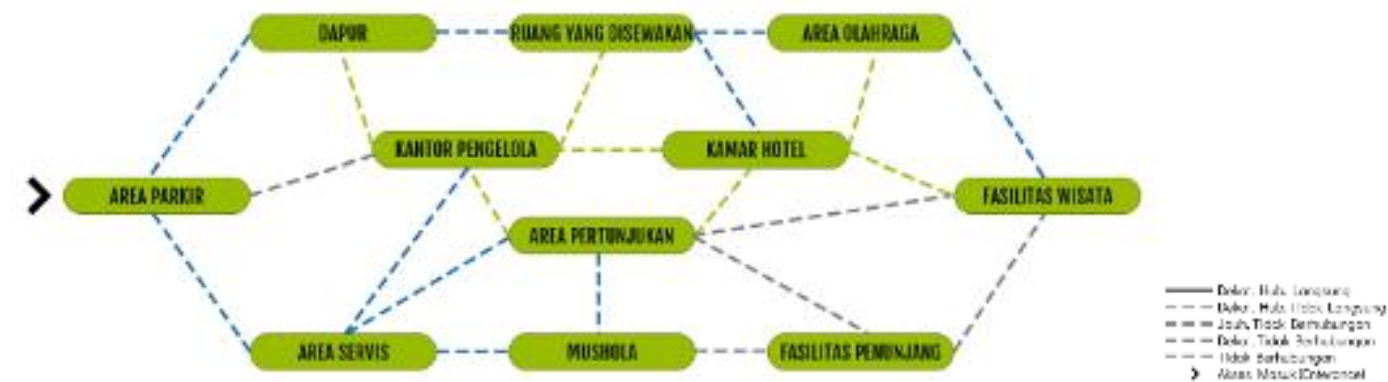

Gambar 2. Analisis Lokasi Perancangan

Sumber: Analisis Penulis, 2021

\section{Analisis Eksternal}

Analisis eksternal memiliki tujuan untuk memperoleh berbagai aspek penataan ruang secara eksternal yang akan menghasilkan analisis dari peletakan, orientasi, sirkulasi, vegetasi dan zonasi. Analisis eksternal memerlukan data umum lokasi yang berlokasi di Danau Lait, Desa Subah, Kabupaten Sanggau yang merupakan bagian dari Provinsi Kalimantan Barat. Daerah beriklim tropis dengan suhu udara serta kelembaban yang tinggi. Secara geografis Danau Lait terletak di Desa Subah yang merupakan salah satu desa yang ada di kecamatan Tayan Hilir yang berada pada bagian barat dari wilayah Kabupaten Sanggau, apabila dilihat dari letak geografisnya desa Subah terletak pada $0^{\circ} 05^{\prime} 14.25^{\prime \prime} \mathrm{LS} 109^{\circ} 58^{\prime} 24.65^{\prime \prime} \mathrm{BT}$.

Hotel resort termasuk ke dalam kawasan wisata yang diperuntukan ke dalam kepariwisataan bagian wisata alam. Pertimbangan dalam pemilihan lokasi tapak berdasarkan teori tentang kriteria hotel resort menurut Kurniasih (2009). Perancangan Hotel Resort Danau Lait berada di wilayah 
administratif Desa Subah. Berdasarkan pertimbangan pemilihan lokasi tapak maka dipilih tiga lokasi yang memenuhi kriteria dan memungkinkan untuk dijadikan alternatif lokasi tapak. Dari analisis yang telah dilakukan, maka dapat disimpulkan bahwa lokasi yang paling memungkinkan sebagai lokasi perancangan Hotel Resort Danau Lait adalah lokasi alternatif 1 yang berlokasi di Danau Lait, Desa Subah Kec. Tayan Hilir, Kab.Sanggau dengan luas tapak $\pm 32.978 \mathrm{~m}^{2}$, KDB maksimal 50\%, KDH minimal 20\%, dan GSB dan GSS yang belum direncanakan.

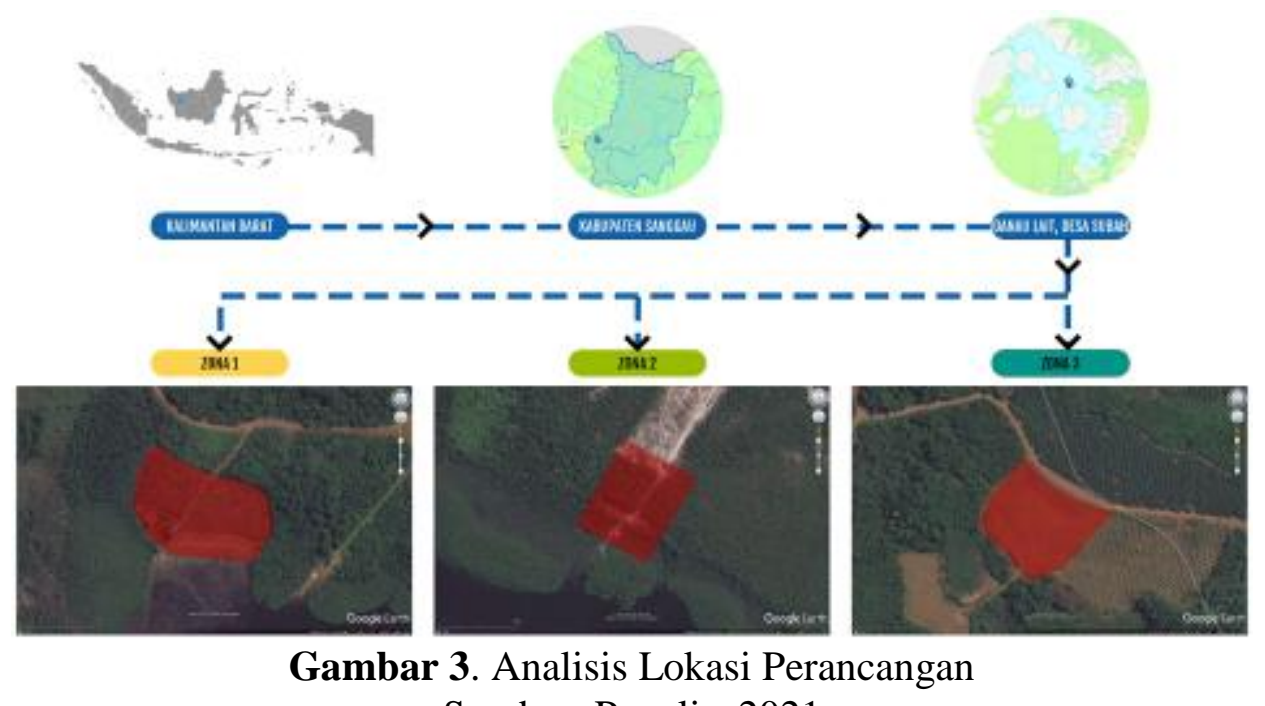

Sumber: Penulis, 2021

\section{Analisis Bentuk}

Hotel Resort Danau Lait menerapkan analisis internal, eksternal dan pendekatan Arsitektur Neo-vernakular yang ditekankan pada fasad bangunan sebagai bentuk dasar. Tahap analisis bentuk dimulai dari tahap awal yakni dari latar belakang yang menjadi dasar dari ide perancangan Hotel Resort Danau Lait yang tergambarkan ke dalam pemahaman terhadap fungsi bangunan, tujuan pembangunan dan aktivitas kegiatan yang ada di luar maupun di dalam. Tahap selanjutnya, berdasarkan pertimbangan kontekstual dan konsep dari perancangan yang dipaparkan dalam analisis yang memperoleh hasil penyesuaian dengan kondisi kontek lingkungan sekitar dan tapak dengan menerapkan konsep neo-vernakular ke dalam perancangan. Selanjutnya pertimbangan terhadap filosofi dan ikonik untuk menjadi dasar referensi antara fungsi dari tapak, bangunan, dan konteks terhadap lingkungan sekitarnya. Berdasarkan penjelasan yang telah dipaparkan di atas. Maka, bentukan dasar dari Hotel Resort Danau Lait diasumsikan bagi besaran massa gubahan berdasarkan jumlah besaran ruang yang sesuai terhadap fungsi dari bangunan hotel resort. Berikut adalah gambar dari analisis bentuk Hotel Resort Danau Lait. 

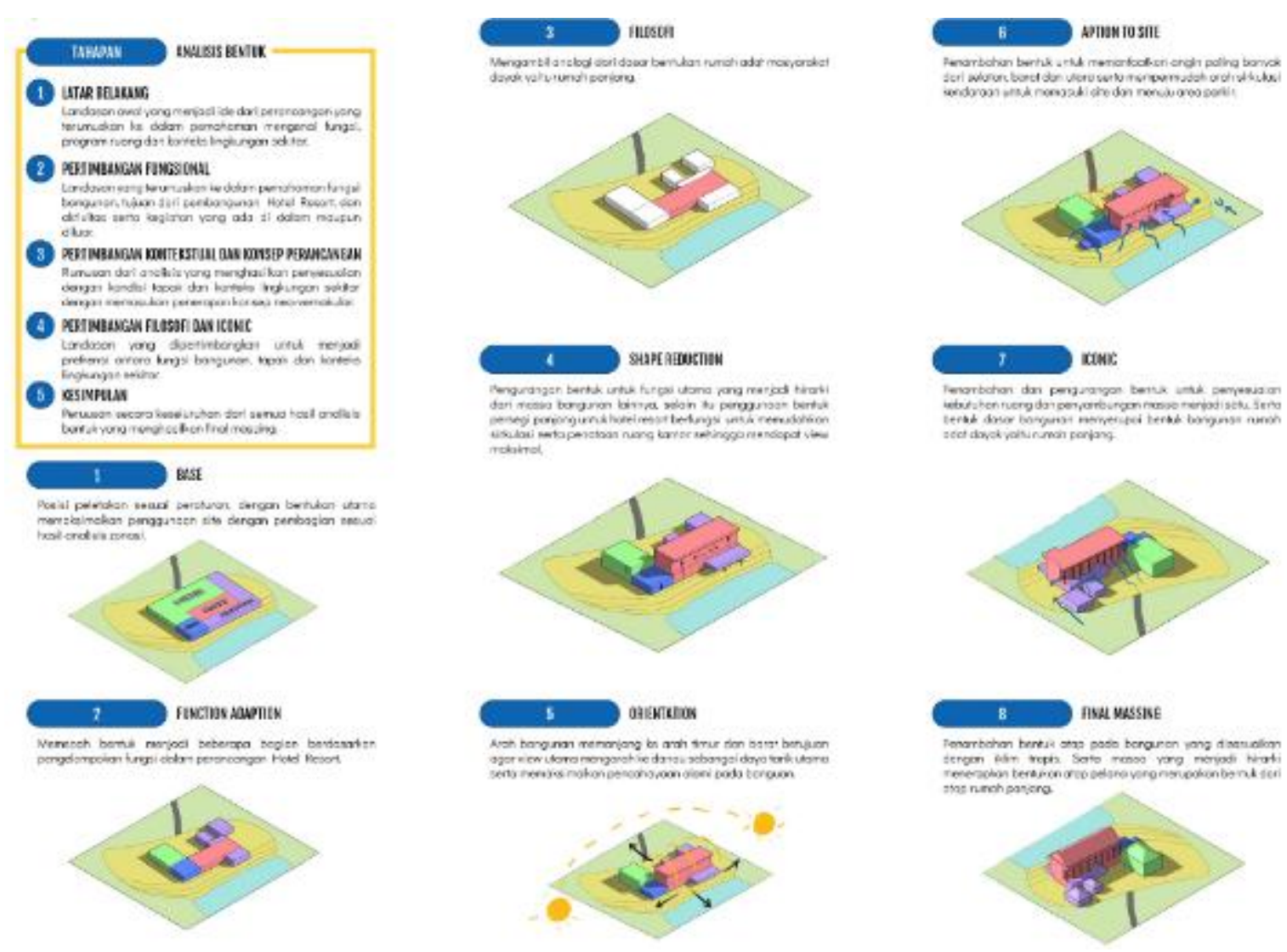

Gambar 4. Analisis Bentuk Sumber: Penulis, 2021

\section{Analisis Struktur}

Analisis pada struktur bangunan dibagi menjadi dua yakni struktur bentang kecil dan struktur bentang lebar. Analisis menggunakan tabel kriteria yang mencakup sistem dan material dari struktur. Berikut adalah analisis struktur pada bangunan. Berdasarkan gambar analisis struktur Hotel Resort Danau Lait. Analisis pada struktur bawah (substructure) mempertimbangkan kondisi struktur tanah yang ada di Danau Lait yakni tanah berjenis tanah dengan daya dukung rendah. Berdasarkan hal tersebut, maka pada bangunan nantinya menggunakan sistem pondasi jenis tidak langsung. Pondasi jenis ini adalah pondasi yang menerus hingga ke tanah keras. Penggunaan struktur bentang lebar pondasi yang dipakai adalah pondasi tiang pancang beton yang bentuk serta jumlah pada pile tergantung dari ukuran modul. Modulasi atau grid 6x6 dan 4x4 menggunakan mini pile. Analisis struktur atas (upper structure) terdiri dari kolom beton bertulang. Pada struktur atap menggunakan truss baja WF. Gording atap menggunakan baja profil C. Penutup lantai menggunakan homogenous tile karena lebih cepat dalam pengerjaan. Struktur dinding menggunakan bata ringan dilapisi dengan plester $1,5 \mathrm{~cm}$. 


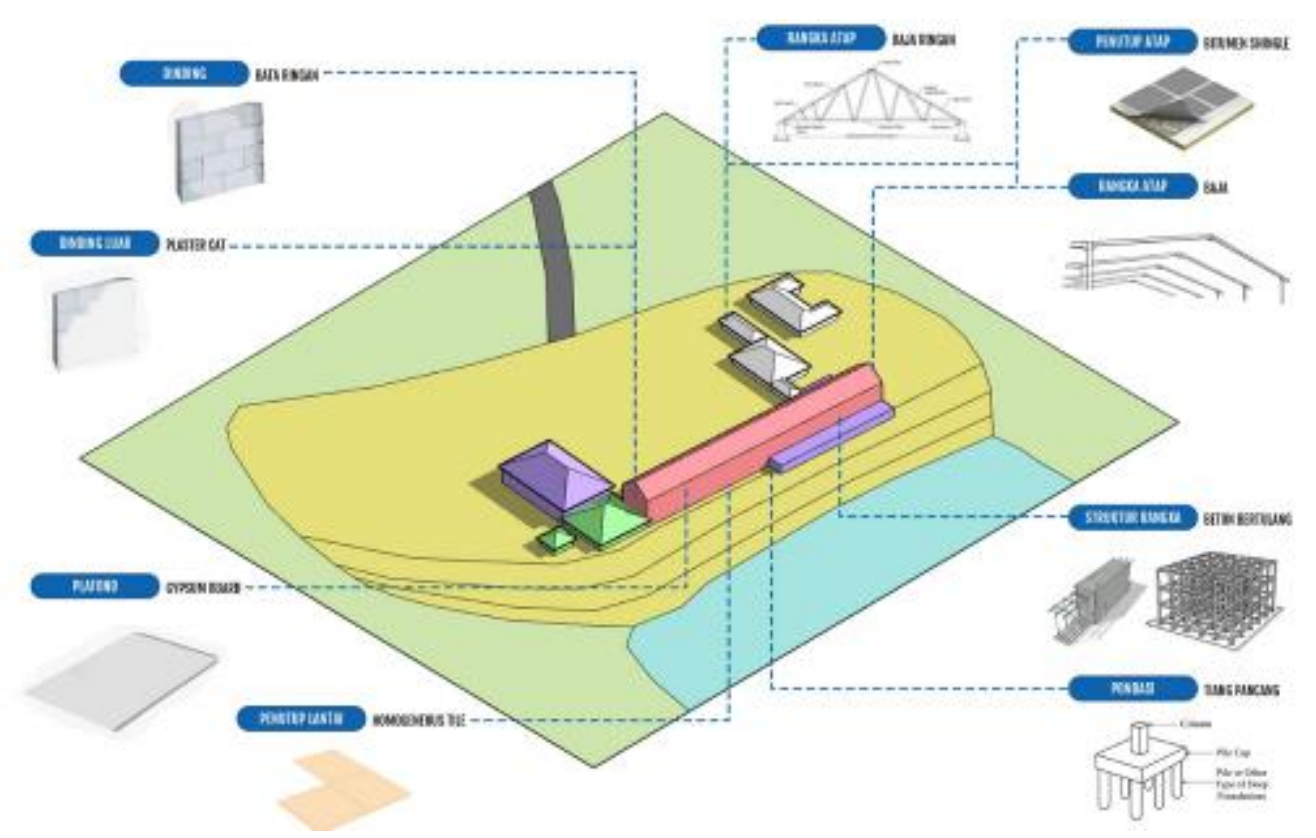

Gambar 5. Analisis Struktur

Sumber: Penulis, 2021

\section{Analisis Utilitas}

Analisis utilitas pada perancangan Hotel Resort Danau Lait terdiri atas sistem jaringan air (plumbing) yang mencakup air bersih dan air kotor, sistem jaringan listrik mencakup listrik, cctv, dan komunikasi. Sistem jaringan keamanan bangunan mencakup penangkal petir dan penanggulangan kebakaran dan sistem persampahan (opsional). Analisis terhadap sistem jaringan air terbagi menjadi dua yaitu sistem jaringan air bersih dan sistem jaringan air kotor. Pada sistem distribusi air bersih menggunakan sistem up feed dan down feed. Pada area sekitar tapak belum terdapat jaringan air bersih pdam. Oleh karena itu, sumber air bersih berasal dari mata air, air sumur galian, air danau dan air hujan. Sebelum dialirkan ke seluruh bangunan air tersebut terlebih dahulu mengalami proses penyaringan. Setelah itu, air ditampung pada GWT kemudian disalurkan menuju tangki air yang berada di lantai dua dan tiga.

Pada lokasi tapak belum terdapat jaringan listrik PLN dan masih dalam tahap perencanaan oleh pemerintah daerah. Berdasarkan wawancara dengan pengelola kawasan wisata Danau Lait menyatakan bahwa pembangunan jaringan listrik terhenti karena pandemi virus Covid-19. Oleh karena itu, sumber jaringan listrik pada bangunan hotel resort menggunakan sumber listrik alternatif seperti panel surya dan generator.

Sistem keamanan pada bangunan mencakup penanggulangan kebakaran dan penangkal petir. Pada analisis penangkal petir dibutuhkan data sambaran petir per tahun suatu wilayah, dikarenakan wilayah Kabupaten Sanggau tidak ditemukan data sambaran petir per tahun maka digunakan data yang paling mendekati yaitu data sambaran petir per tahun Kota Pontianak. Angka IKL (Isokeraunik Level) pada Kota Pontianak adalah 60.00/tahun yang digolongkan sebagai daerah dengan kerawanan terhadap petir yang tinggi berdasarkan (SNI 03-7015-2004 Sistem Proteksi pada Bangunan Gedung). Pertimbangan perlunya penangkal petir pada suatu bangunan dapat dihitung menggunakan perhitungan menurut (Juwana, 2005). Berdasarkan perhitungan perhitungan kebutuhan penangkal petir Hotel Resort Danau Lait adalah $\mathrm{N}=\mathrm{A}+\mathrm{B}+\mathrm{C}+\mathrm{D}+\mathrm{E}$ maka merujuk data diperoleh $3+7+1+0+3=$ 14. Hasil dari perhitungan menunjukkan bahwa nilai yang diperoleh $=14$ yang berarti bangunan Hotel Resort Danau Lait sangat dianjurkan untuk menggunakan sistem penangkal petir. Pada Hotel Resort Danau Lait tidak menggunakan sistem persampahan secara spesifik. Oleh karena itu perencanaan sistem persampahan hanya bersifat opsional. 


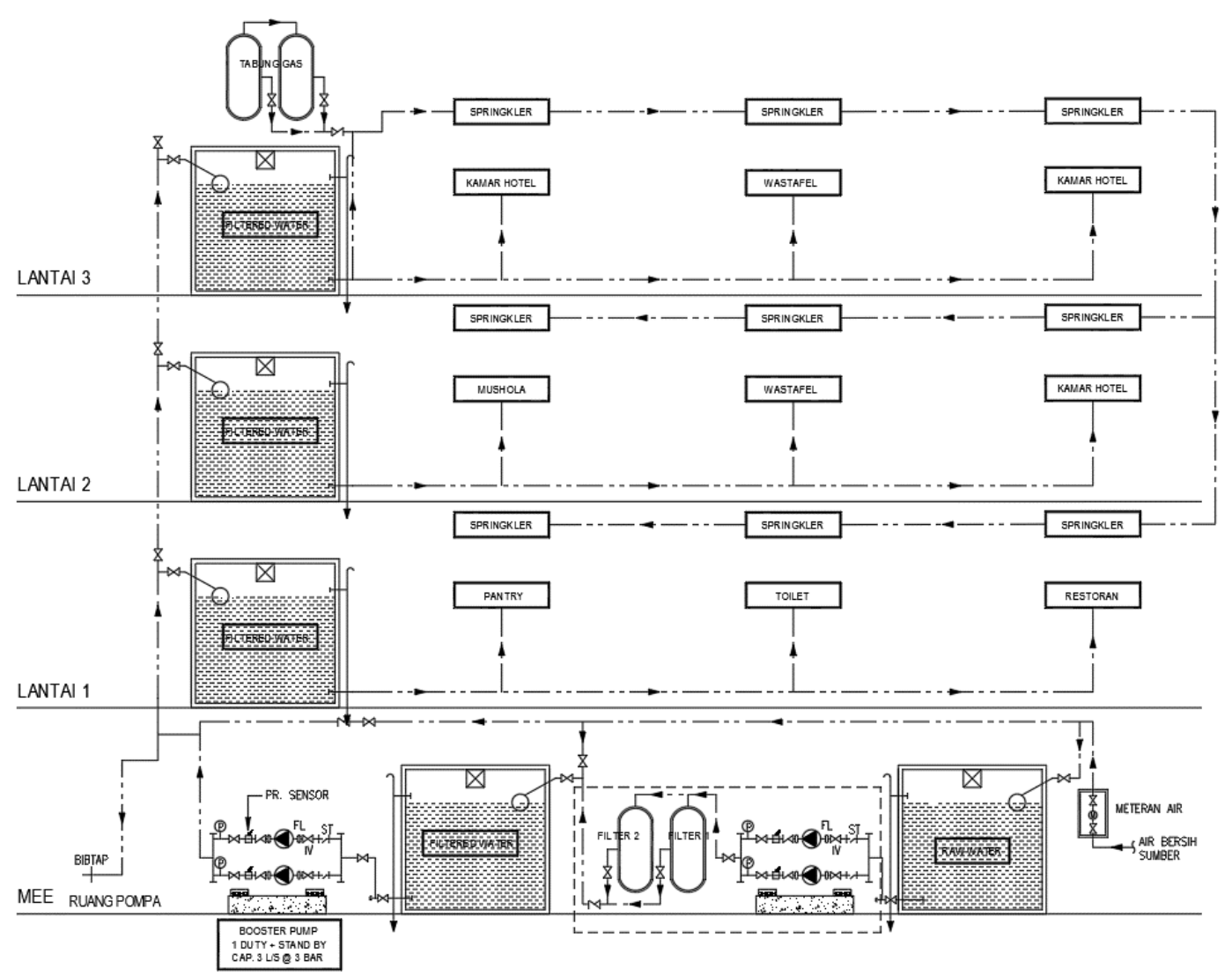

Gambar 6. Skema Distribusi Air Bersih

Sumber: Penulis, 2021

\section{Analisis Fisika Bangunan}

Analisis fisika bangunan merupakan analisis terhadap persyaratan-persyaratan seperti pencahayaan, penghawaan, dan akustik pada bangunan. Berikut ini adalah analisis fisika bangunan pada Hotel Resort Danau Lait. Analisis aspek penghawaan pada perancangan Hotel Resort Danau Lait mempunyai alternatif jenis sistem penghawaan pada ruangan yaitu penghawaan buatan dan penghawaan alami. Penghawaan alami merupakan jenis penghawaan yang baik untuk ruangan. Mengoptimalkan sirkulasi udara pada ruangan dapat mempengaruhi suhu ruang yang akan berpengaruh pada kenyaman. Penerapan sistem penghawaan dalam ruang seperti cross ventilation dengan diselimuti secondary skin bangunan dapat meminimalkan dampak suhu panas (Jones, 1980). Pada ruangan tertentu diberi void untuk memaksimalkan sirkulasi udara pada ruangan. Selain penggunaan sistem penghawaan alami, penghawaan buatan juga diperlukan untuk ruang-ruang tertentu seperti dapur restoran, kamar mandi, toilet, ruang genset, ruang mesin, dan kamar hotel. Maka dari itu, pada Hotel Resort Danau Lait menggunakan penghawaan buatan berupa AHU (Air Handling Unit) yang pendistribusiannya melalui sistem ducting. Pada analisis aspek pencahayaan juga menggunakan dua alternatif yaitu pencahayaan alami dan pencahayaan buatan. Penggunaan pencahayaan alami dioptimalkan ke semua ruang dengan memaksimalkan bukaan. Berdasarkan Peraturan Menteri Pekerjaan Umum dan Perumahan Rakyat Republik Indonesia Nomor 22 Tahun 2018 Tentang Pembangunan Gedung Negara bahwa besar bukaan minimal yaitu $6-10 \%$ dari luas dinding. Analisis aspek pada akustika bertujuan agar mendapatkan solusi dari permasalahan kebisingan yang mengganggu aktivitas pengguna dalam bangunan. Hotel Resort Danau Lait menggunakan salah satu sumber listrik dari mesin generator. Oleh karena itu, diperlukan perlakuan khusus pada ruang mesin generator agar suara bising yang dihasilkan oleh mesin tidak mengganggu 
kenyamanan penghuni hotel. Solusi dari permasalahan tersebut dengan membuat ruangan mesin dengan dinding yang kedap suara.

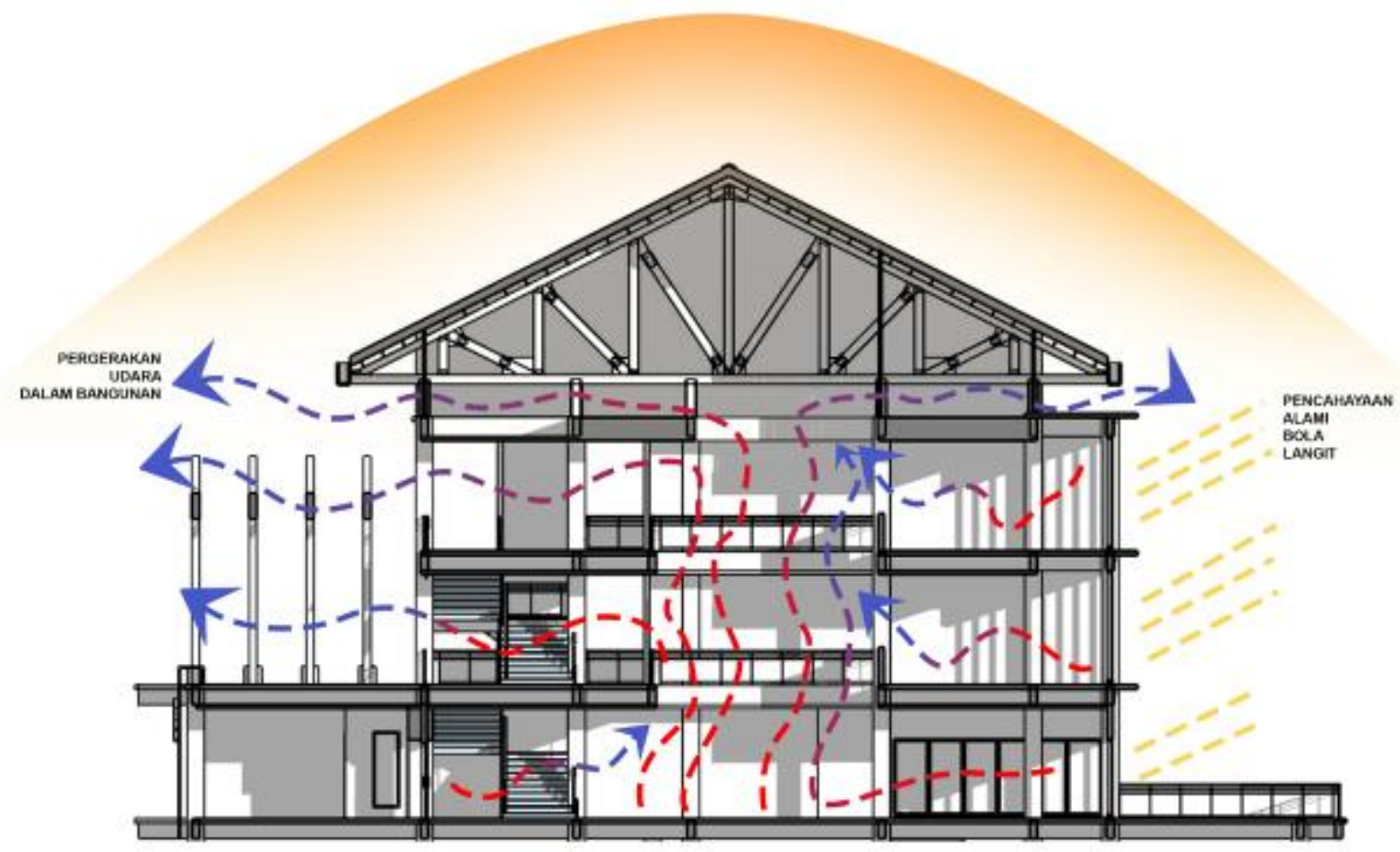

Gambar 7. Analisis Penghawaan dan Pencahayaan Sumber: Penulis, 2021

\section{Hasil Perancangan}

Hasil perancangan didapat setelah melalui analisis konseptual sebelumnya. Selanjutnya diterapkan ke dalam rencana gambar kerja yang digunakan sebagai landasan perancangan Hotel Resort Danau Lait. Adapun isi dari hasil rancangan berupa gambar site plan, denah, tampak dan visualisasi tiga dimensi suasana eksterior dan interior.

Hasil analisis serta konsep pada perancangan Hotel Resort Danau Lait diperoleh hasil gambar pra-rancangan berupa site plan yang menggambarkan hubungan antara ruang luar dan ruang dalam. Rancangan Hotel Resort Danau Lait meliputi bangunan utama, bangunan mini market, gym, cottage serta area-area pendukung seperti kolam renang dan area camping. Pendukung lainnya berupa area parkir dan taman. 


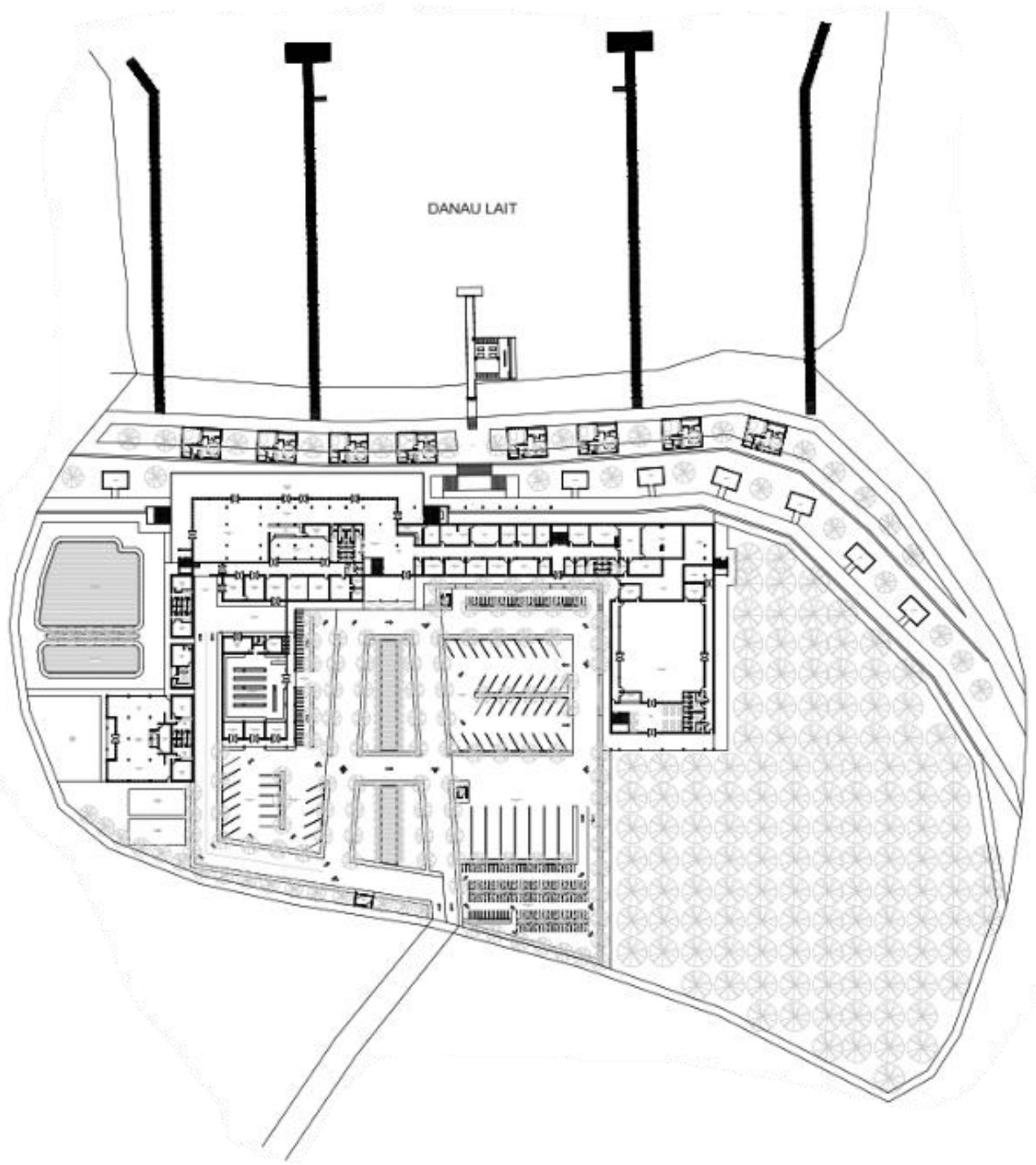

Gambar 8. Site plan

Sumber: Penulis, 2021

Lantai pertama pada bangunan utama terdiri dari ruang-ruang publik seperti lobby, restaurant dan ruang konferensi, serta terdapat pula ruang-ruang pengelola hotel resort. Selain itu, terdapat area servis pada sisi barat bangunan. Sedangkan, pada lantai dua dan tiga diperuntukan untuk kamar hotel. Lantai menuju lantai 3 dapat diakses menggunakan tangga dan lift. 
9

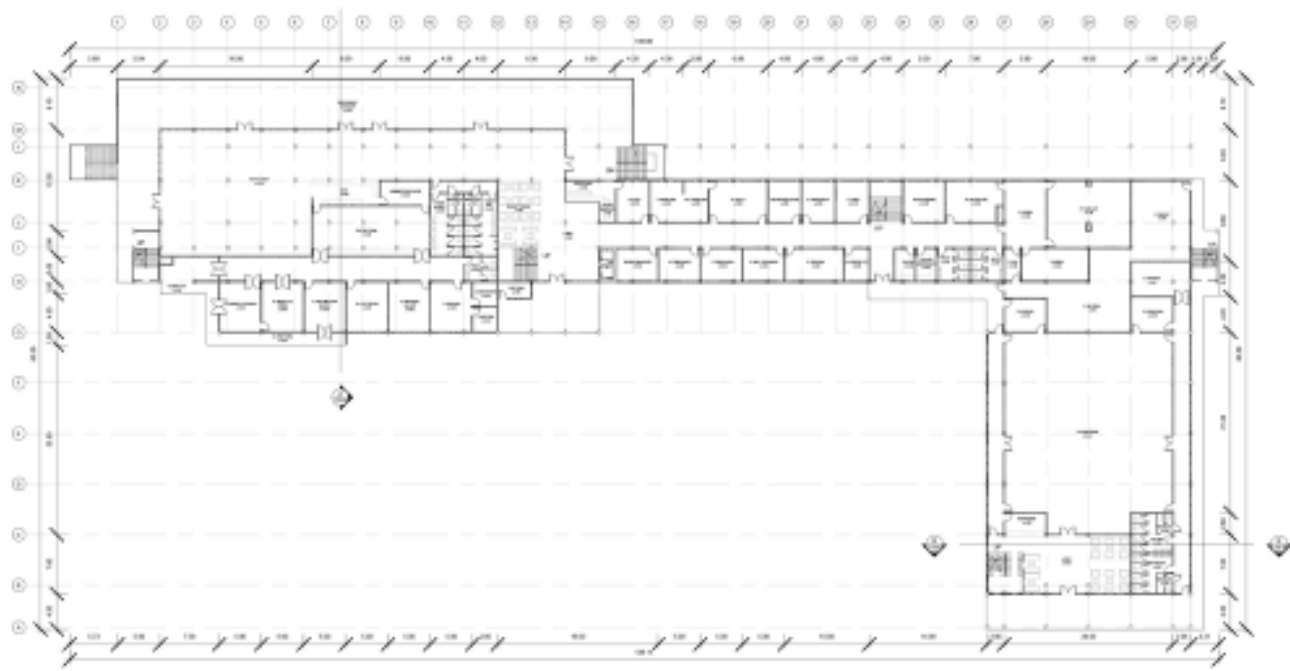

Gambar 9. Denah Lantai 1

Sumber: Penulis, 2021

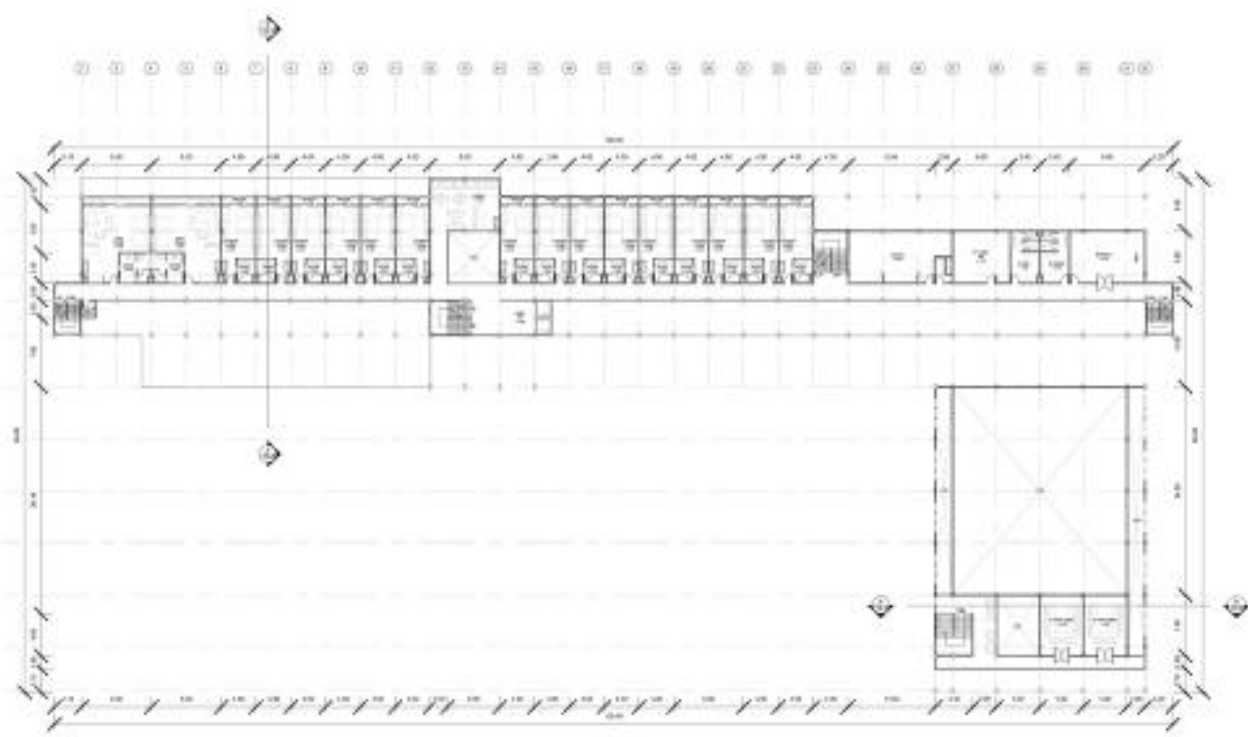

Gambar 10. Denah Lantai 2

Sumber: Penulis, 2021

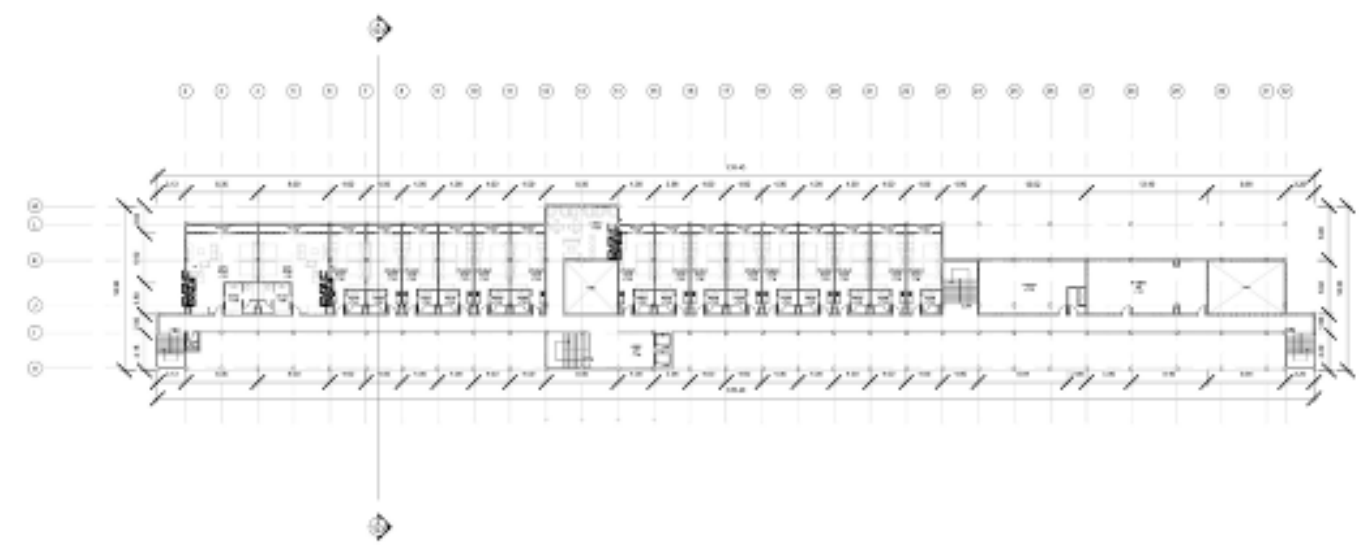

Gambar 11. Denah Lantai 3

Sumber: Penulis, 2021 
Pada Gambar tampak, gaya arsitektur, warna, proporsi, material dan estetika. Fasad pada bangunan menggunakan tema Local Sense dengan penekanan neo-vernakular. Hal ini mempengaruhi fasad dari bentuk bangunan hingga warna. Menggunakan warna yang netral dan terlihat bersih. Penggunaan warna yang dominan warna putih yang dipadukan dengan warna coklat kayu serta warna hitam.

Tampak depan dan belakang bangunan merupakan bentuk respon terhadap site dengan arah orientasi utama yang menghadap ke arah jalan masuk menuju site dan ke arah Danau Lait. Tampak fasad sekilas mirip dengan bentuk rumah adat suku Dayak yaitu menyerupai bentuk Rumah Panjang. Hal ini dikarenakan penggunaan konsep pendekatan neo-vernakular pada fasad bangunan maka diambil bentuk dari rumah adat suku Dayak. Pengambilan bentuk Rumah Panjang juga bertujuan untuk merespon terhadap iklim tropis.

Fasad bangunan bagian belakang memaksimalkan bukaan berupa jendela. Selain berfungsi untuk memaksimalkan sirkulasi udara. Hal ini juga bertujuan untuk memaksimalkan pemandangan dari bangunan ke arah danau. Tampak samping kiri dan kanan menunjukkan bentuk atap dari bangunan. Bentuk atap merupakan bentuk atap pelana dengan kemiringan $30^{\circ}$.

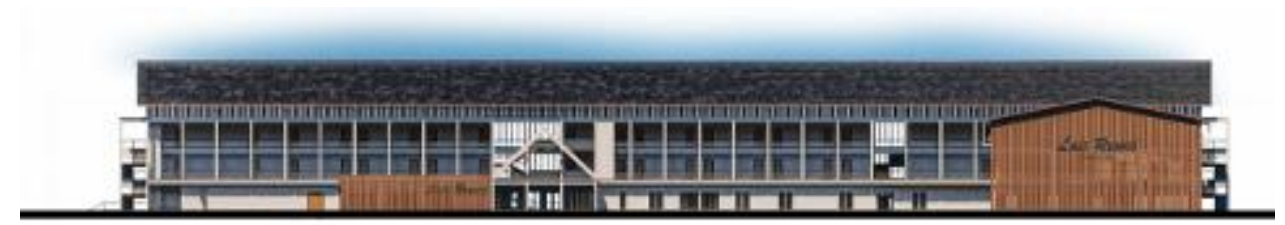

Gambar 12. Tampak Depan

Sumber: Penulis, 2021

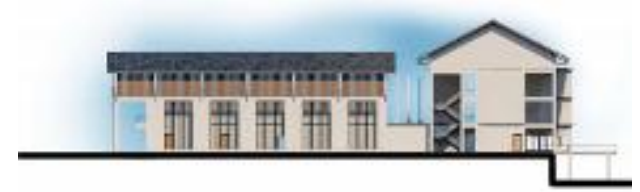

Gambar 13. Tampak Samping Kanan Sumber: Penulis, 2021

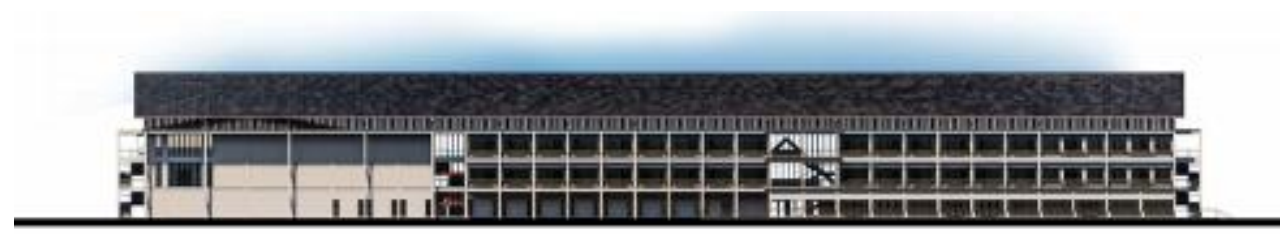

Gambar 14. Tampak Belakang

Sumber: Penulis, 2021

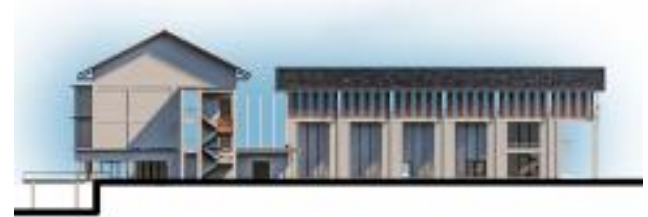

Gambar 15. Tampak Samping Kiri

Sumber: Penulis, 2021

Hotel Resort Danau Lait merupakan bangunan hotel resort dengan tema Local Sense dengan pendekatan perancangan neo-vernakular pada fasad bangunan yang memadukan unsur lokal dan modern. Berikut ini merupakan visualisasi suasana eksterior dari Hotel Resort Danau Lait. 
Suasana isometric view menunjukkan jumlah massa yang terdapat pada site Hotel Resort Danau Lait. Penataan massa pada site menunjukkan sumbu linear. Menjadikan bangunan utama sebagai pusat hirarki. Penataan massa juga mempertimbangkan aspek view. View utama kawasan lebih ditekankan ke arah selatan. Hal ini bertujuan untuk mendapatkan view maksimal ke pemandangan Danau Lait.

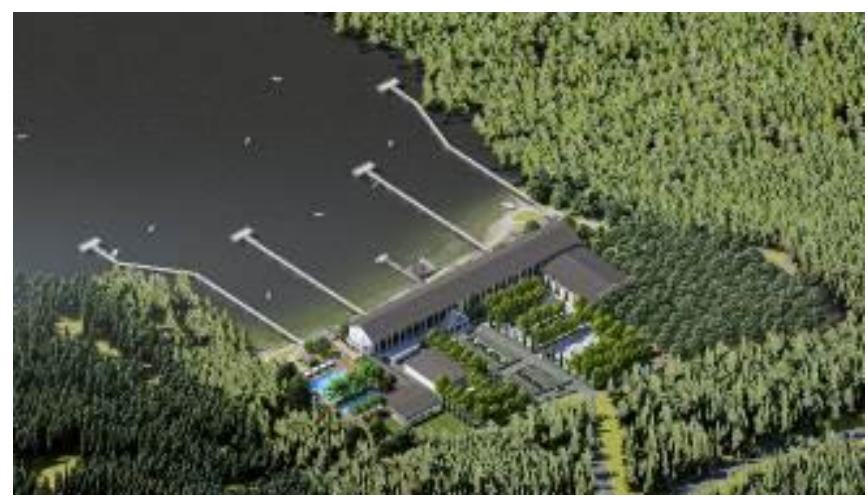

Gambar 16. Suasana Isometric View

Sumber: Penulis, 2021

Vegetasi pada site berupa vegetasi tipe peneduh yang di sebarkan di lokasi-lokasi yang telah ditentukan. Penggunaan vegetasi tipe peneduh bertujuan untuk membuat suasana nyaman pada site.

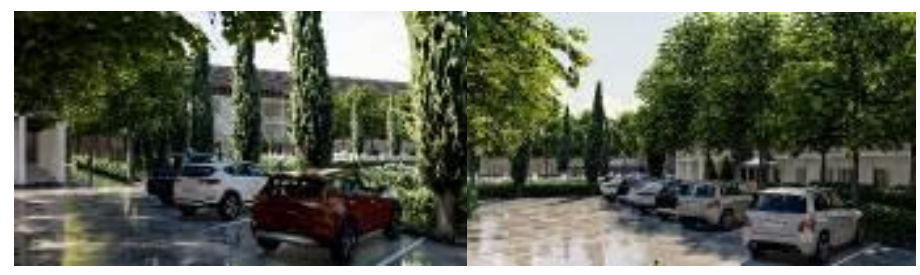

Gambar 17. Suasana Eksterior Parkiran

Sumber: Penulis, 2021

Pada halaman depan bangunan juga ditanami vegetasi berupa bunga yang ditata dengan sumbu lurus mengarah ke drop off serta pintu masuk utama bangunan Hotel Resort Danau Lait. Penataan seperti ini bertujuan agar tidak membingungkan pengunjung saat memasuki kawasan Hotel Resort Danau Lait.

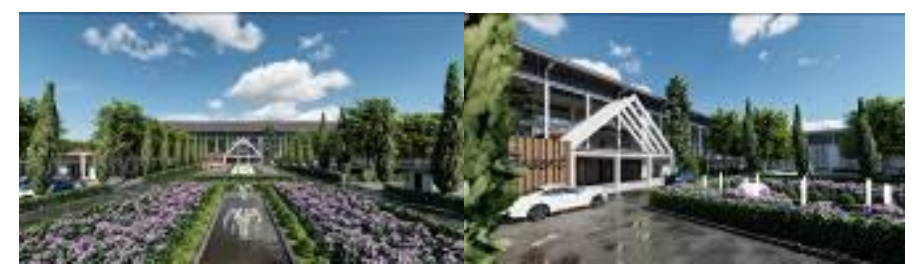

Gambar 18. Suasana Eksterior Halaman Depan dan Drop Off

Sumber: Penulis, 2021

Suasana interior merupakan hasil dari perancangan ruang dalam yang memperlihatkan suasana ruang-ruang tertentu pada Hotel Resort Danau Lait. Suasana interior memperlihatkan pemilihan material dinding, warna, serta perabot pengisi ruangan. 


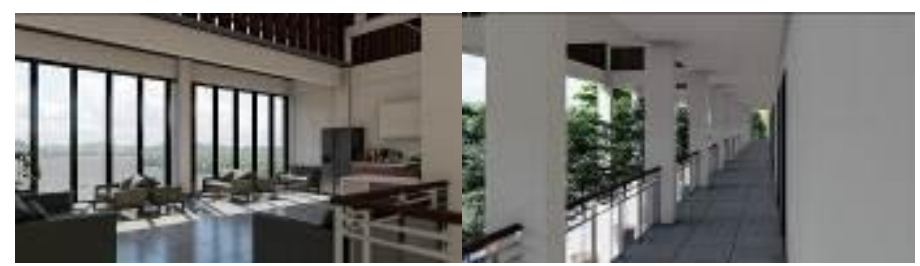

Gambar 19. Suasana Lounge dan Koridor

Sumber: Penulis, 2021

Lounge merupakan area santai tamu Hotel Resort Danau Lait. Sembari bersantai tamu juga langsung dapat menikmati langsung pemandangan danau dari lounge. Lounge dilengkapi dengan sofa yang empuk dan nyaman serta dilengkapi dengan fasilitas pembuat kopi. Warna dinding menggunakan warna putih. Hal ini bertujuan agar tamu hotel dapat mendapatkan suasana yang tenang dan damai serta memfokuskan pandangan ke danau. Bukaan jendela yang besar memberikan pencahayaan alami pada lounge. Pada Suasana koridor dibuat terbuka tanpa adanya dinding yang menyekat. Hal ini bertujuan untuk memaksimalkan sirkulasi udara dan juga saat tamu berjalan di koridor menuju ke kamar dapat sambil menikmati pemandangan sekitar dengan leluasa.

Suasana kamar standar dirancang dengan memperhatikan kenyamanan tamu. Penggunaan material dominan kayu memberikan kesan alami pada ruang kamar. Memadukan paduan warnawarna hangat pada ruangan kamar dimaksudkan agar memberikan kesan nyaman. Selain itu, pada ruang kamar memiliki bukaan jendela yang lebar serta balkon yang berfungsi sebagai area bersantai tamu sambil menikmati pemandangan danau. Perabot yang digunakan pada ruang kamar standar merupakan perabotan dangan bentuk yang minimalis. Hal ini dapat memberikan kesan simpel pada ruanggan serta cocok untuk ruangan yang ditujukan sebagai tempat beristirahat.

Kamar suite memiliki luasan yang lebih luas dari kamar standar. Kamar ini ditujukan untuk tamu dengan ekonomi menengah ke atas. Maka dari itu suasana yang diciptakan harus bersifat mewah. Namun, pada rancangan kamar suite Hotel Resort Danau Lait tetap mempertahankan kesan alami dangan penggunaan material kayu. Pada lantai bangunan menggunakan lantai parket dengan jenis corak yang soft. Hal ini memberikan kesan sejuk serta nyaman pada ruangan kamar. Pada plafon kamar diberi lampu jenis led strip. Hal ini dimaksudkan agar memberikan kesan mewah pada ruangan. Kemudian, pemilihan perabot dengan warna-warna netral agar dapat menciptakan kesan harmonis pada ruangan.

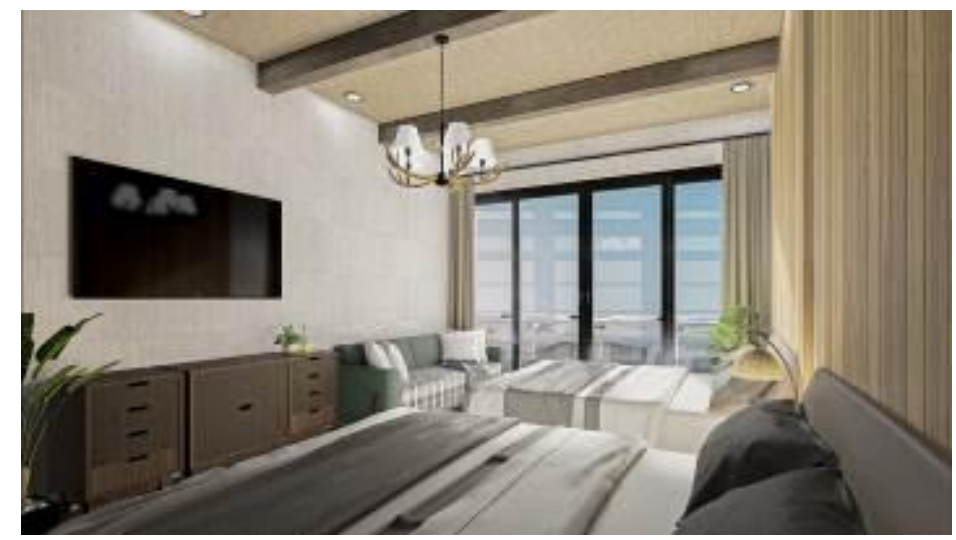

Gambar 20. Suasana Interior Kamar Standar

Sumber: Penulis, 2021 


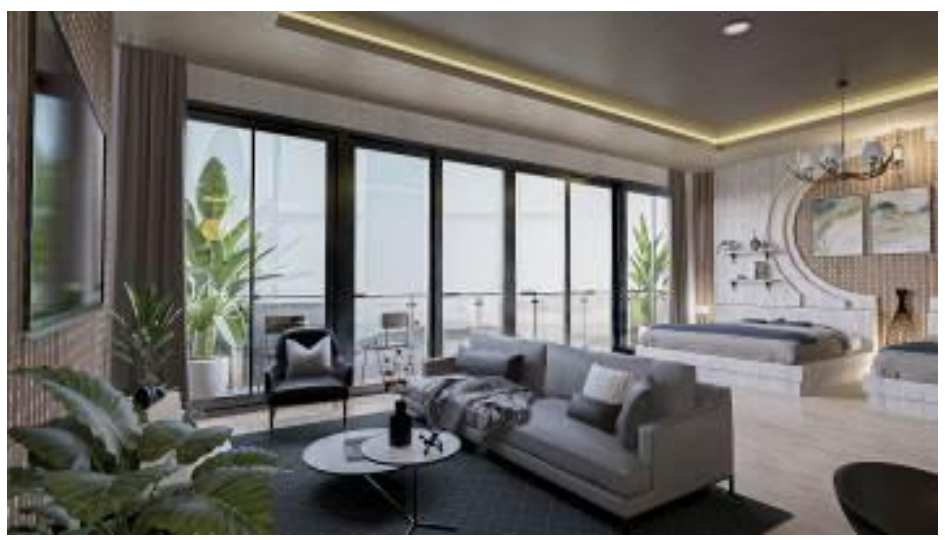

Gambar 21. Suasana Interior Kamar Suite

Sumber: Penulis, 2021

\section{Kesimpulan}

Hotel Resort Danau Lait merupakan hotel resort yang memberikan fasilitas penginapan, makan dan minum, olahraga, hiburan dan fasilitas lainnya yang ditujukan kepada pengunjung yang berwisata ke Danau Lait. Hotel resort dirancang dengan pendekatan arsitektur neo-vernakular yang memadukan unsur tradisional dan modern pada bangunan. Penggunaan pendekatan neo-vernakular lebih ditekankan pada fasad bangunan bertujuan agar menciptakan ciri khas tersendiri pada hotel resort ini. Selain itu, dengan dibangunnya Hotel Resort Danau Lait dimaksudkan agar dapat mengakomodasi pengunjung yang berwisata ke Danau Lait serta meningkatkan jumlah kunjungan wisatawan.

\section{Ucapan Terima Kasih}

Terima Kasih kepada Allah SWT atas rahmat dan karunia yang telah diberikan kepada penulis, sehingga dapat menyelesaikan Proyek Tugas Akhir ini. Terima kasih juga kepada orang tua penulis dan keluarga besar, serta para dosen yang telah membimbing dan memberi dukungan.

\section{Daftar Acuan}

Dirjen Pariwisata. (1988). Tentang Pelaksanaan Ketentuan Usaha dan Penggolongan Hotel. Indonesia John, M. E. (1987). Kamus Inggris-Indonesia. Jakarta: Gramedia

Jones, J. (1980). Design Methods: Seeds of Human Future. New York: John Wiley \& Sons

Juwana, J. S. (2005). Panduan Sistem Bangunan Tinggi. Jakarta: Erlangga

Kurniasih, S. (2006). Prinsip Hotel Resort. Skets (Vol. 2). Jakarta: Akademi Pariwisata Trisakti

Kurniasih, S. (2009). Prinsip Hotel Resort: Studi Kasus Putri Duyung Cottage 51 Ancol Jakarta Utara. Progdi: Arsitektur Fakultas Teknik Universitas Budi Luhur

Marlina, E. (2008). Panduan Perancangan Bangunan Komersial. Yogyakarta: Andi

Neufert, E. (1996). Data Arsitek Jilid 1. Jakarta: Erlangga

Neufert, E. (2002a). Data Arsitek Jilid 2. Jakarta: Erlangga

Neufert, E. (2002b). Data Arsitek Jilid 3. Jakarta: Erlangga

Pendit, N. S. (1999). Ilmu Pariwisata. Jakarta: Akademi Pariwisata Trisakti

Snyder \& Catanese. (1989). Pengantar Arsitektur. Jakarta: Erlangga 